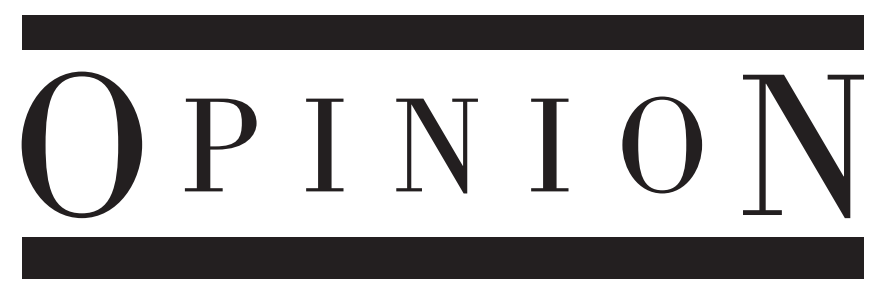

\section{Northridge 20 Years After}

Urban earthquakes such as the 1994 M 6.7 Northridge earthquake provide unique moments of clarity for those of us working on earthquake hazards. I recall being jolted awake at 4:31 a.m., 17 January 1994, in my Pasadena home. As I hurried to my U.S. Geological Survey (USGS) office on the Caltech campus, I remember wondering what the day would bring. Was the epicentral region sparsely populated, or had we just taken a direct hit to urbanized Los Angeles (LA)? We now know that, although damaging shaking extended into the LA basin, it was the San Fernando Valley that experienced truly violent shaking; five strong-motion accelerometers recorded peak ground velocities (PGV) of more than $1 \mathrm{~m} / \mathrm{s}$. Although the attack was over in 15 seconds, it left behind about $\$ 20$ billion in damage and millions of terrified Angelenos, especially those living in the San Fernando Valley.

Despite the intense shaking, the official death toll was only 57 . We clearly dodged a bullet that winter morning. Almost everyone in the epicentral region was asleep in wood houses or low-rise wood apartments. California wood structures are resilient in earthquakes; they are naturally lightweight and stiff enough that the plasterboard walls do not crack as the house adjusts to the gravity load from, say, a large dinner party. This stiffness brings the benefit that they are also strong. To be sure, the violent shaking in the San Fernando Valley caused extensive damage to wood houses, but none of them collapsed. Sixteen people died when part of the ground story of a wood Northridge Meadows apartment building collapsed, but many other wood apartment buildings did not collapse.

Reinforced-concrete-frame (RCF) buildings did not fare as well. Short reinforced-concrete-wall buildings (e.g., 7-Eleven stores) survived, but frightening collapses struck other concrete structures that would have been filled with people several hours later. In a sense, Northridge was a replay of the 1971 M 6.7 San Fernando earthquake, which also struck early in the morningwood homes and short concrete-wall buildings did not collapse, but a few RCF buildings did.

The collapse of RCF buildings in 1971 prompted important changes to building codes. Unfortunately, more than 1000 concrete buildings had already been constructed in metropoli- tan LA using the older techniques; these buildings are commonly referred to as nonductile concrete-frame buildings. Figure 1 shows approximate contours of the PGV during the Northridge earthquake and locations of pre-1994 buildings at least four stories tall. Several colleagues have cautioned that some buildings likely are misidentified, so do not take this figure too literally-but the pattern is valid. The buildings are separated into two categories: (1) Circles represent pre-1975 concrete buildings; many are nonductile and may not have survived the type of shaking that happened in the northern San Fernando Valley in 1994 and 1971. (2) Triangles represent pre-1994 steel-frame buildings. Clearly, the urban parts of LA with frame buildings of at least four stories were not shaken as violently as the San Fernando Valley suburbs were.

Probably the largest surprise in the Northridge earthquake was the brittle fracture of the key welds in steel momentresisting frame buildings (Reis and Bonowitz, 2000). Most steel-frame buildings are designed so that, at the largest deformations, plastic yielding of steel (plastic hinges) should occur mostly in horizontal beams; plastic hinges in vertical columns are to be avoided because they tend to form premature collapse mechanisms. The welds are critical because they carry the loads between the columns and the beams.

Several steel-frame buildings in the southern San Fernando Valley were very strongly shaken, so inspectors expected to find postearthquake evidence of plastically bent beams. However, inspectors did not find any such beams; instead, the welded moment-resisting connections fractured. Subsequent full-scale laboratory tests confirmed that the capacity of the welded connections was less than the forces required to plastically bend the beams. This was an enormous surprise, and it meant that the steel-frame buildings were far more brittle than the designers had intended. It would take many pages to more completely describe this problem and the measures taken to mitigate it for new construction. Let me just say that, at present, most California steel-frame buildings continue to have pre-1994 brittle welds. Simulations of 20-story steel-frame buildings suggest that they are three to five times more likely to collapse than buildings with sound welds when intensely shaken (Olsen et al., 2008). Furthermore, simulations of earthquakes on the Hollywood fault, the Santa Monica fault, 


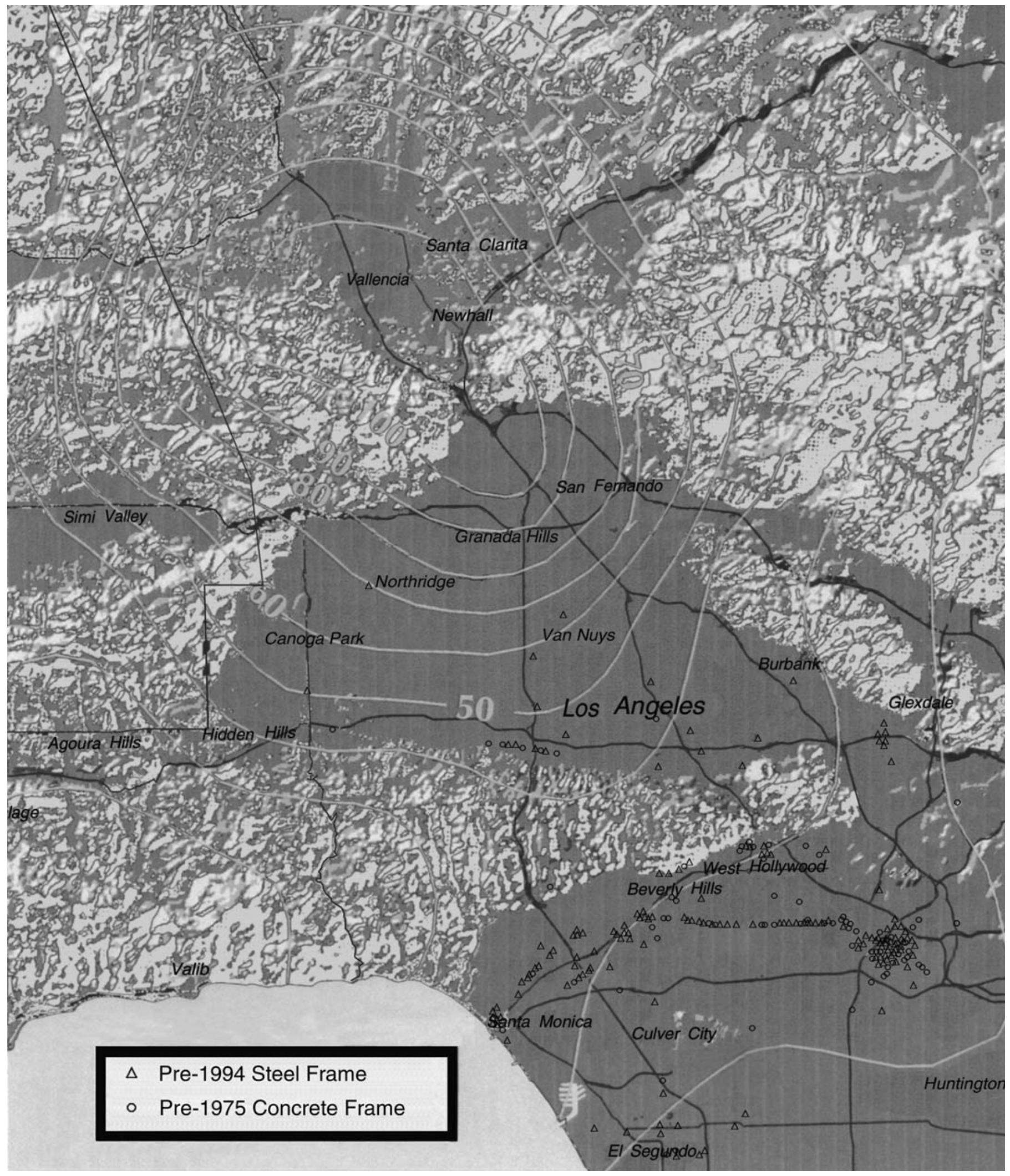

A Figure 1. Contours of peak ground velocity in the 1994 M 6.7 Northridge earthquake. Circles represent pre-1975 concrete buildings; many of these buildings are nonductile and they may not have survived the type of shaking that happened in the northern San Fernando Valley in 1994 and 1971. Triangles represent pre-1994 steel-frame buildings. Building data are from the LA County Tax Assessor's files and have not been checked for accuracy. Adapted from Wald et al. (1996). 
the Newport-Inglewood fault, and the Puente Hills fault all show that violent shaking could someday occur in regions with these older, brittle frame buildings (both concrete and steel) (Day et al., 2005; Olsen, 2008).

It is now almost 20 years since we produced Figure 1, which supports the idea that we did dodge a bullet in 1994 . Unfortunately, the gun is still loaded and cocked, because very few of the fragile frame buildings have been retrofitted. The earthquake research community is well aware of the brittleframe issue, but the general community is not. A recent Los Angeles Times article on nonductile concrete frames (Lin et al., 2013) surprised most Angelenos. Why don't residents of these buildings know that they live in buildings that earthquake professionals have known for decades to be of dubious safety? Pre-1975 concrete frames seem to be the most alarming problem, but pre-1994 brittle steel frames also present a genuine concern. The occupants have no clue, and the building owners have little motivation to pursue this problem.

Furthermore, why isn't there a program in place to at least tell people that they are in harm's way? There is lots of blame to go around.

1. The City of Los Angeles should have compiled a list of potentially hazardous buildings, and the occupants of these buildings should have been made aware of the list. Although lawsuits would have inevitably followed, I doubt any would have been successful; public safety is the highest priority. Los Angeles is not alone here; many other cities have not tackled this issue.

2. The California Seismic Safety Commission should have made this issue plain and clear to all four California governors since 1994, who should have acted on the commission's recommendations.

3. The National Institute of Standards and Technology (NIST) should be systematically compiling quantitative, easily accessible information on the shaking resilience of different types of buildings and developing a national database of the resilience of individual buildings. The $\mathrm{Na}$ tional Highway Transportation Safety Authority publishes a list of the safety of all automobiles-why are buildings different? NIST is the lead agency in the National Earthquake Hazards Reduction Program (NEHRP), and it ultimately bears the brunt of the responsibility for ensuring that these problems are effectively addressed.

4. The USGS has focused its ever-diminishing resources on probabilistic seismic-hazard assessments, but it is also critically important for the USGS to collaborate with NIST to simulate the impact of specific earthquakes on different urban environments. The ShakeOut (see Porter et al., 2011) is a fine example of how Earth scientists and earthquake engineers can collaborate to highlight specific problems. Unfortunately, the ShakeOut's impact was all too fleeting.
5. The President and Congress need to rediscover the earthquake problem. NIST has never had a meaningful NEHRP budget (despite its advertised key role). The USGS budget has steadily declined to less than one-third its size of 30 years ago. To add insult to injury, NEHRP has not been reauthorized since 2004 .

Of course, there are some bright spots in this story. For example, the California Department of Transportation (Caltrans) began systematically retrofitting all nonductile concrete bridge columns more than 20 years ago. The California Office of Statewide Health Planning and Development (OSHPD) has been systematically reviewing the structural capacity of hospitals. When appropriate, structural retrofits are required with the intention that the hospitals can remain functional during earthquakes. These Caltrans and OSHPD programs have been expensive and difficult. The bridge retrofit program is essentially finished, whereas the hospital retrofit programs are an ongoing struggle.

In September 2013, Caltrans opened the new East Span of the San Francisco-Oakland Bay bridge, and Californians were told that it is designed for the 1500-year earthquake. Fifteen-hundred years is a long time, and lots of horrible nonearthquake things are likely to visit our society in that period. Policy makers and the general public seem to have interpreted this 1500-year design target as evidence that the problem of building for earthquakes is mostly solved. The recent LA Times story, though, presents a jarring contrast. It showed that many Californians were very surprised to learn that they might be crushed between the floors of a modern multistory California building. More concern and confusion will follow when the public learns that some steel-frame high rises may collapse in the near-source region of large earthquakes.

Personally, I have been around this business long enough to have seen previous generations of earthquake professionals reassure the public that, while the older buildings are possible hazards, the newest buildings will perform well. At one time this was said for the nonductile concrete-frame buildings that we now fear. Perhaps it is possible that we have now achieved an appropriate resistance strategy, but few of our buildings have really been tested. It is going to be a giant experiment when we get a direct strike to one of our cities. I somehow doubt we will be talking much about 1500-year failure recurrence times after such an event.

I consider myself an earthquake professional; I am a seismologist and an earthquake engineer. I have often claimed that our research provides the information necessary to take actions that will decrease future tragedies and that we need not wait for a future disaster to acquire actionable knowledge. However, this optimistic view has been challenged by our collective failure to respond strongly to the near miss that occurred with the Northridge earthquake. At the end of the day, this collective 
failure is the responsibility of the entire community of earthquake professionals, including Earth scientists, earthquake engineers, emergency responders, and public policy makers. It is a sure thing that if tens of thousands of Americans perish in a future urban earthquake, we will focus our attention on how we can better protect the public. Wouldn't it be nice to do it before the disaster? $\mathbf{z}$

\section{REFERENCES}

Day, S. M., J. Bielak, D. Dreger, S. Larsen, R. Graves, A. Pitarka, and K. B. Olsen (2005). Lifelines program task 1A03: 3D ground motion simulation in basins, Technical Report, Pacific Earthquake Engineering Research Center.

Lin, R.-G., II, R. Xia, and D. Smith (2013). Concrete Risks, Los Angeles Times, 13 October 2013, front page.

Olsen, A. H. (2008). Steel Moment-Resisting Frame Responses in Simulated Strong Ground Motions: or How I Learned to Stop Worrying and Love the Big One, Ph.D. Thesis, Department of
Civil Engineering and Applied Mechanics, California Institute of Technology, Pasadena, California.

Olsen, A., B. Aagaard, and T. Heaton (2008). Long-period building response to earthquakes in the San Francisco Bay area, Bull. Seismol. Soc. Am. 98, 1047-1065.

Porter, K., K. Hudnut, S. Perry, M. Reichle, C. Scawthorn, and A. Wein (2011). Forward to Special Issue: The ShakeOut Scenario, Earthq. Spectra 27, 235-237.

Reis, E., and D. Bonowitz (2000). State of the Art Report on Past Performance of Steel Moment-Frame Buildings in Earthquakes, Report No. FEMA-355E, SAC Joint Venture.

Wald, D., T. Heaton, and K. Hudnut (1996). The slip history of the 1994 Northridge, California, earthquake determined from strongmotions, GPS, and leveling-line data, Bull. Seismol. Soc. Am. 1B, S49-S70.

\author{
Thomas Heaton \\ Earthquake Engineering Research Laboratory \\ California Institute of Technology
}

